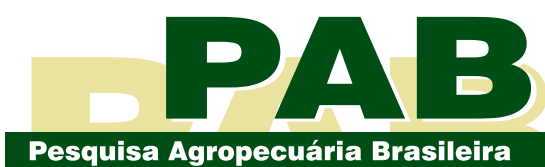

ISSN 1678-3921

Journal homepage: www.embrapa.br/pab

For manuscript submission and journal contents, access: www.scielo.br/pab
Food Technology/ Original Article

\section{Ultrasound-assisted emulsions with biopolymers for spray-drying of lemongrass essential oil}

\begin{abstract}
The objective of this work was to evaluate the partial replacement of gum arabic by modified starches on the spray-drying microencapsulation of lemongrass (Cymbopogon flexuosus) essential oil. The ultrasound-assisted emulsions were prepared with $30 \%(\mathrm{w} / \mathrm{w})$ of wall material, $7.5 \%(\mathrm{w} / \mathrm{w})$ of oil load, and 1:1 (w/w) replacement ratio for all treatments. After 16 hours, the incompatibility observed between gum arabic and octenyl succinic anhydride (OSA) starch did not affect the obtained microparticles, since the treatment with OSA starch, partially replacing gum arabic, showed the best results for the process yield and for the oil charge retention after spray-drying process, and the treatment showed Newtonian viscosity close to that of the treatment prepared with gum arabic. Maltodextrin dextrose equivalent 10 (10DE) shows an oil load similar to that of the treatment with gum arabic, while the presence of maize maltodextrin DE20 reduces the content of encapsulated oil and the efficiency of the drying process due to the adherence of particles to the chamber. Therefore, the partial substitution of gum arabic is an alternative for the formation of emulsions, for the spray-drying microencapsulation of lemongrass essential oil.
\end{abstract}

Index terms: Cymbopogon flexuosus, atomization, gum arabic, ultrasonication.

\section{Emulsões assistidas por ultrassom com biopolímeros para secagem por atomização de óleo essencial de capim-limão}

Resumo - O objetivo deste trabalho foi avaliar a substituição parcial da goma arábica por amidos modificados, na microencapsulação do óleo essencial de capim-limão (Cymbopogon flexuosus), por meio de secagem por atomização. As emulsões assistidas por ultrassom foram preparadas com $30 \%(\mathrm{~m} / \mathrm{m})$ de material de parede, $7,5 \%(\mathrm{~m} / \mathrm{m})$ de carga de óleo e $1: 1(\mathrm{~m} / \mathrm{m})$ de taxa de substituição para todos os tratamentos. Após 16 horas, a incompatibilidade observada entre a goma arábica e o anidrido octenil succínico (AOS) não afetou as micropartículas obtidas, uma vez que o tratamento com o amido AOS, em substituição parcial à goma arábica, apresentou os melhores resultados quanto ao rendimento do processo e à retenção de carga de óleo após a secagem por atomização, e o tratamento mostrou viscosidade newtoniana próxima à do tratamento preparado com goma arábica. A maltodextrina dextrose equivalente $10(10 \mathrm{DE})$ mostra uma carga de óleo semelhante à do tratamento com goma arábica, enquanto a presença de maltodextrina de milho DE20 reduz o teor de óleo encapsulado e a eficiência do processo de secagem, em razão da aderência das partículas à câmara. Portanto, a substituição parcial da goma arábica mostra-se como alternativa para a formação de emulsões, para a microencapsulação por meio de secagem por atomização do óleo essencial de capim-limão.

Termos para indexação: Cymbopogon flexuosus, atomização, goma arábica, ultrassonicação. 


\section{Introduction}

Natural products are currently preferred for food safety and preservation due to the demand of consumers. Essential oils exhibit antimicrobial functions, and studies have shown that lemongrass essential oil could be used in order to reduce the proliferation of Listeria monocytogenes (Hadjilouka et al., 2017) - the main causative agent of foodborne illness (listeriosis), and Penicillium digitatum (Zheng et al., 2015) - the causative agent of green mold and the main postharvest citrus disease, - which are focuses of global concern for economics and public health.

Lemongrass essential oil is obtained by steam distillation of Cymbopogon flexuosus (Nees ex Steud.) Will. Watson, a plant commonly consumed in the form of tea, containing monoterpenes, in which citral, a natural mixture of two isomers (Gaonkar et al., 2016), is the main component present in the structure.

The encapsulation process is a viable alternative to protect essential oils due to their high volatility and bioactive compound instability. Firstly, for the encapsulation process by spray drying, the preparation of emulsions occurs through the addition of wall materials (biopolymers) (Campelo et al., 2017). Spontaneously immiscible liquids which are thermodynamically unstable form the emulsions; therefore, the system easily loses equilibrium through flocculation and coalescence. Regarding emulsionforming technology, ultrasonic cavitation is a wellknown and proven technology capable of transforming the immiscible liquids into stable droplets. Ultrasonic waves vaporize the particles by the drastic reduction of pressure, which modifies the conformation, providing the oil dispersion in water (Dehshibi et al., 2018).

The emulsions play a key role in the efficiency and stability of the oil microparticles produced in the encapsulation, especially through spray drying. This process consists of transforming the high-moisture product into a low-moisture powder by atomizing emulsion droplets (Schmitz-Schug et al., 2016). The selection of an appropriate wall material is primordial for the spray-drying encapsulation process, in order to avoid undesirable changes during the process and to obtain powders with favorable physical properties (Fernandes et al., 2014).

Wall material is generally composed of polymers, and gum arabic is one of the most commonly used materials for spray drying, due to its high solubility, low viscosity, good emulsifying properties, and high oxidative stability (Niu et al., 2016). Gum arabic, a hydrocolloid produced by natural exudation of acacia trees, is ideal for the encapsulation of lipids. It is composed of a highly branched arrangement of simple sugars, such as galactose, arabinose, and rhamnose. Although it is highly used, gum arabic shows high cost and low availability, which encourages the research for substitutes (Binsi et al., 2017). Thus, maltodextrin, a material derived from the partial hydrolysis of starch, has been used as a secondary wall material, and may be used in combination with gums in atomized emulsions. Among the advantages of using maltodextrin are the low cost, neutral flavor, aroma, and low viscosity at high concentrations. Maltodextrins with low dextrose equivalent (DE), a parameter that measures the extent of starch hydrolysis, are considered more appropriate, since they may confer a better physical stability to the wall system (Otálora et al., 2015; Li et al., 2017).

The production of modified starches is a potential option that has been used for overcoming one or more limitations of native starches. When produced by esterification with octenyl succinic anhydride (OSA), the partially hydrolyzed waxy starch obtains a hydrophobic element from octenyl groups, which results in whole molecules with an amphiphilic character. Such modification gives good emulsifying properties to the OSA starch, even at low concentrations, which makes it an excellent wall material for the retention of volatiles during spray drying (Sweedman et al., 2013).

Therefore, the objective of this work was to evaluate the partial replacement of gum arabic by modified starches, on the spray-drying microencapsulation of lemongrass essential oil.

\section{Materials and Methods}

Indian lemongrass (Cymbopogon flexuosus) essential oil was acquired from Ferquima Indústria e Comércio Ltda.,Vargem Grande Paulista, SP, Brazil. The wall materials were from different suppliers, as follows: gum arabic (Colloïdes Naturels Comercial Ltda., São Paulo, SP, Brazil), maize maltodextrin with dextrose equivalent 10 (10DE) and dextrose equivalent 20 (20DE) (Maltogil, Cargill Agrícola S/A, Porto Ferreira, SP, Brazil), cassava maltodextrin (10DE) (Neomalt 5010B, Cassava S/A, Maripá, PR, Brazil), and modified starch with octenyl succinic anhydride 
(OSA) (Capsul, Ingredion UK Limited, Wythenshawe, Manchester, United Kingdom).

Firstly, the wall material powders were dissolved in distilled water, prior to the emulsification process, and kept overnight to ensure a full saturation of biopolymer molecules. The percentage of solids (wall material) used in the feed solution was $30 \%(\mathrm{w} / \mathrm{w})$ for all treatments (Oliveira et al., 2018). Each treatment was prepared using gum arabic (T1) and its combination with modified starches (T2, T3, T4, and T5) at 1:1 $(w / w)$ ratio (Table 1). Lemongrass essential oil was progressively added to the wall material solution under stirring at 3,500 rpm for $2 \mathrm{~min}$, using a rotorstator blender (Ultra-Turrax T18 basic, IKA Works Inc., Wilmington, NC, USA). Oil load employed was $7.5 \%(\mathrm{w} / \mathrm{w})$, based on the total emulsion volume. After the homogenization process by mechanical stirring, the emulsions were immediately subjected to ultrasonication at $160 \mathrm{~W}$ of nominal power (Sonifier Cell Disruptor Branson S-450D, Branson Ultrasonics Corporation, Brookfield, CT, USA), $20 \mathrm{kHz}$, for 2 min. The height contact was standardized to $30 \mathrm{~mm}$ between the ultrasonic probe and the emulsions.

The effect of partial substitution of gum arabic by modified starches, in the biopolymer formulations added with lemongrass oil, was evaluated for emulsion properties (density, droplet size, stability, and rheological behavior), yield of the spray-drying process and oil load efficiency. The morphology and aggregation status of the droplets were observed using an optical microscope E100 LED (Nikon Instruments Inc., Tokyo, Japan). An aliquot of each emulsion was placed on the slide, covered with a coverslip and examined with 40X (T1 to T4) and 100X objective lens (T5). Calculations were performed for $\left[D_{32}\right]$ (Eq. 1) and $\left[D_{43}\right]$ (Eq. 2), by using the laser diffraction particle

Table 1. Composition of the ultrasound-assisted emulsions with biopolymers for spray drying of lemongrass (Cymbopogon flexuosus) essential oil.

\begin{tabular}{ll}
\hline Treatment & \multicolumn{1}{c}{ Wall material $(\mathrm{w} / \mathrm{w})$} \\
\hline T1 & $60 \mathrm{~g}$ gum arabic \\
$\mathrm{T} 2$ & $30 \mathrm{~g}$ gum arabic $+30 \mathrm{~g}$ cassava maltodextrin $10 \mathrm{DE}$ \\
$\mathrm{T} 3$ & $30 \mathrm{~g}$ gum arabic $+30 \mathrm{~g}$ maize maltodextrin 10DE \\
$\mathrm{T} 4$ & $30 \mathrm{~g}$ gum arabic $+30 \mathrm{~g}$ maize maltodextrin $20 \mathrm{DE}$ \\
$\mathrm{T} 5$ & $30 \mathrm{~g}$ gum arabic $+30 \mathrm{~g}$ OSA starch \\
\hline
\end{tabular}

$\mathrm{DE}$, dextrose equivalent; OSA, octenyl succinic anhydride. size analyzer Mastersizer 3000 (Malvern Instruments Ltd, Malvern, Worcestershire, England), to determine the weighted average diameter by area and volume, respectively, and span to determine the width of the droplet size distribution (Eq. 3).

$\left[\mathrm{D}_{32}\right]=\frac{\Sigma \mathrm{n} \times \mathrm{d}^{3}}{\Sigma \mathrm{n} \times \mathrm{d}^{2}}$

$\left[D_{43}\right]=\frac{\Sigma \mathrm{n} \times \mathrm{d}^{4}}{\Sigma \mathrm{n} \times \mathrm{d}^{3}}$

in which: $\left[\mathrm{D}_{32}\right]$ is the surface diameter of particles $(\mu \mathrm{m}) ;\left[\mathrm{D}_{43}\right]$ is the volumetric diameter of particles $(\mu \mathrm{m}) ; \mathrm{d}$ is the droplet diameter; and $\mathrm{n}$ is the number of droplets between two consecutive diameters $(\mu \mathrm{m})$.

$\operatorname{Span}=\frac{\left(\mathrm{d}_{90}-\mathrm{d}_{10}\right)}{\mathrm{d}_{50}}$,

in which: span is the polydispersity index (PDI); and the variables $\mathrm{d}_{10}, \mathrm{~d}_{50}$, and $\mathrm{d}_{90}$ are droplet diameters at $10 \%, 50 \%$, and $90 \%$ cumulative volume, respectively.

The emulsion density was measured using a pycnometer and calculated by the equation 4 . For the experiment, distilled water (liquid with tabulated density) was also used.

$\rho_{\mathrm{e}}=\frac{\mathrm{m}_{\mathrm{e}}}{\mathrm{m}_{\mathrm{w}}} \rho_{\mathrm{w}}^{25^{\circ} \mathrm{C}}$

in which: $\rho_{\mathrm{e}}$ is the emulsion density $\left(\mathrm{g} \mathrm{mL}^{-1}\right) ; \mathrm{m}_{\mathrm{e}}$ is the emulsion mass $(\mathrm{g}) ; \mathrm{m}_{\mathrm{w}}$ is the mass of distilled water $(\mathrm{g})$; and $\rho_{\mathrm{w}}^{25^{\circ} \mathrm{C}}$ is the density of distilled water at $25^{\circ} \mathrm{C}$ (tabulated value). The $\mathrm{m}_{\mathrm{e}}$ and $\mathrm{m}_{\mathrm{w}}$ were determined experimentally from the subtraction of the weight of the empty pycnometer.

Immediately after the emulsification process, $100 \mathrm{~mL}$ aliquots of each emulsion were transferred to $250 \mathrm{~mL}$ graduated cylinders, sealed, and stored at $25^{\circ} \mathrm{C}$. The volume of the oil phase was observed 2,4 , 16 , and 24 hours after the preparation of emulsions.

The rheological behavior of the samples was determined at $25^{\circ} \mathrm{C}$, using a rheometer HAAKE ReoStress 6000 (Thermo Scientific, Karlsruhe, BadenWürttemberg, Germany), equipped with a thermostatic bath HAAKE A10 (Thermo Scientific) and a universal temperature control system HAAKE UTM Controller (Thermo Scientific). The measurements were carried out using a concentric cylinder geometry sensors cup - CCB25 DIN and rotor - CC25 DIN Ti (Thermo 
Scientific) with $5.3 \mathrm{~mm}$ standard gap. Sample volumes (16.1 mL each one) were used to carry out the measurements. To eliminate thixotropy (the influence of time on the solution flow behavior), each sample was subjected to three continuous shear rate ramps (rising, downward, and rising) ranging from 0 to $300 \mathrm{~s}^{-1}$ for $3 \mathrm{~min}$ for each curve. The Newton's law (equation 5), power law (equation 6), and Herschel-Buckley (equation 7) models were fitted to experimental data of the second-rising curve (flow curve).

$\sigma=\mu \dot{\gamma}$

$\sigma=\mathrm{K} \dot{\gamma}^{\mathrm{n}}$

$\sigma=\sigma_{\mathrm{o}}+\mathrm{K} \dot{\gamma}^{\mathrm{n}}$

in which: $\sigma$ is the shear stress $(\mathrm{Pa}) ; \mu$ is the Newtonian viscosity (Pa s); $\dot{\gamma}$ is the shear rate $\left(\mathrm{s}^{-1}\right) ; \mathrm{K}$ is the consistency index $\left(\mathrm{Pa} \cdot \mathrm{s}^{\mathrm{n}}\right) ; \mathrm{n}$ is the flow behavior index; and $\sigma_{0}$ is the yield stress $(\mathrm{Pa})$.

The obtained emulsions were subjected to the drying process in a spray dryer equipment MSD 1.0 (Labmaq, Ribeirão Preto, SP, Brazil) equipped with double fluid atomizer. The drying operational conditions were as follows: inlet temperature at $170^{\circ} \mathrm{C}$; atomizing air pressure of $200 \mathrm{kPa}$; air flow rate $35 \mathrm{~L} \mathrm{~min}^{-1}$; feed rate of $0.9 \mathrm{~L}$ per hour; and outlet temperature at $110^{\circ} \mathrm{C}$. Dried powders were collected, weighed, wrapped in aluminum foil, and stored in a refrigerator at approximately $4^{\circ} \mathrm{C}$.

The yield (\%) of the spray-drying process corresponds to the powder mass collected after drying in relation to the dry mass of the feed according to the following equation:

$Y(\%)=\frac{m_{p}}{m_{f}} \times 100$

in which: $\mathrm{Y}(\%)$ is the process yield; $\mathrm{m}_{\mathrm{f}}$ is the dry mass of the carrier material fed in the process and the lemongrass essential oil in the food emulsion, in dry basis; and $\mathrm{m}_{\mathrm{p}}$ is the product collected after the drying process, in dry basis.

The oil load analysis was performed to determine the amount of essential oil (g) per $100 \mathrm{~g}$ of microparticles. Hydrodistillation was performed using the Clevenger apparatus for the essential oil separation of. The process occurred until the oil volume remained constant, and the corresponding weight extracted was determined by oil density $[\%(\mathrm{w} / \mathrm{w})]$ that was previously measured. This distillation method is widely used to extract volatile compounds, such as essential oil (Okoh et al., 2016).

The experiment was performed in a completely randomized design with five treatments and three replicates. The results of the different treatments were subjected to the analysis of variance, followed by the test of Scott-Knott, at 5\% probability, using the statistical package Statistical Analysis System (SAS University Edition, Cary, NC, United States). The models were fitted to the experimental data of the flow curves using the SAS University Edition, and the graphs were plotted using SigmaPlot software 11.0 (Systat Software Inc., California, CA, United States).

\section{Results and Discussion}

The different polymeric matrices formed by each of the wall materials (biopolymers) used in the preparation of emulsions have direct effects on the mean diameter of droplets (Carneiro et al., 2013). The size distribution in volume of the droplets in relation to the droplet diameter is shown in Figure 1, and the size

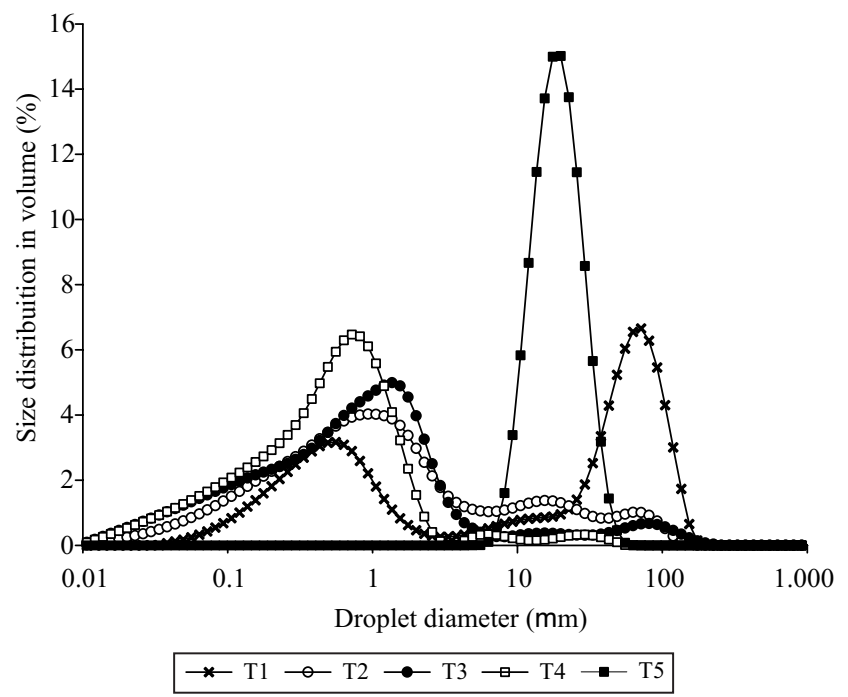

Figure 1. Droplet size distribution of the ultrasoundassisted emulsions with biopolymers for spray drying of lemongrass (Cymbopogon flexuosus) essential oil. T1, gum arabic; T2, gum arabic + cassava maltodextrin 10DE; T3, gum arabic + maize maltodextrin 10DE; T4, gum arabic + maize maltodextrin 20DE; T5, gum arabic + OSA starch. 
and span values of the emulsion droplets are shown in Table 2.

The replacement of gum arabic by maltodextrin caused a decrease of droplet diameter; and cassava maltodextrin (10DE) showed greater polydispersity, according to span value, while the substitution by OSA starch showed the lowest span value, and consequently, lower polydispersity, with Gaussian droplet distribution tendency (Kokkala \& Särkkä, 2015). The span is a value related to the distribution homogeneity of the oil droplet size, and the closer it is to zero, the more uniform and narrow is the distribution (Silva \& Meireles, 2015). However, larger droplets formed during the emulsifying process tend to have lower stability with greater agglomeration and phase separation. Coalescence and Ostwald ripening are processes that increase the droplet size and destabilize emulsions (Erdmann et al., 2017).

The characteristics and morphology of droplets were evaluated with the aid of an optical microscope to determine the differences among treatments (Figure 2). By performing a visual analysis of the emulsion droplets prepared with OSA starch, differences for coloration were observed, and they were more brownish. Moreover, it is possible to observe in the micrographs a greater presence of bubbles in the T5 compared to the others. The maize-20DE (T4) and cassava-10DE (T2) maltodextrin combinations formed closer and more compact droplets, despite the great similarity between their coloration with that of maize maltodextrin (10DE). As to T1 (gum arabic), the treatments added with maltodextrin were more similar for the coloration of droplets. Gum arabic is a hydrocolloid used specially in the food industry for the emulsification of flavor oil, since it is an anionic gum that has a negative charge, which favors the formation of an electrostatic complex (Naderi et al., 2020).

During the drying process of the emulsion, the ideal is to avoid any type of phase separation, such as partial spontaneous coalescence, which generates instability in the system (Goibier et al., 2017). Emulsion stability can be determined by evaluating the amount of liquid drained or oil separated from the original emulsion. The way the emulsion is formed (mechanical or chemical) influences its stability (Zhang et al., 2017). Moreover, the density of components used in its preparation influences the system stability and the final density of the emulsion (Sui et al., 2017). Density is a parameter that measures the mass concentration degree in a given volume, and it has commercial and technological importance.

The observed stability and the averages of the density values obtained from the emulsions are shown in Table 2. According to the results, only the treatment consisting of the mix of gum arabic and OSA starch (T5) showed different stability behavior in comparison to the other treatments and showed lower density.

The emulsion prepared only with gum arabic (T1) showed a very homogeneous aspect. Regardless of the botanical source and dextrose equivalency, treatments with maltodextrin (T2 to T4) also remained stable for 24 hours after their formation, and they were able to use the emulsion for atomization process for a long time. Considering that any type of instability in the phase formation is detrimental to the homogeneity of the final product, phase separations are not desired. The addition of the OSA starch (T5) together with gum arabic contributed to the system destabilization, and it was the only treatment showing coalescence, indicating a lack of compatibility between these two

Table 2. Average diameter by volume $\left(D_{43}\right)$ and area $\left(D_{32}\right)$, span, stability, density, and Newtonian viscosity $(\mu)$ of the ultrasound-assisted emulsions with biopolymers for spray drying of lemongrass (Cymbopogon flexuosus) essential oil ${ }^{(1)}$.

\begin{tabular}{|c|c|c|c|c|c|c|}
\hline Treatment & {$\left[\mathrm{D}_{43}\right](\mu \mathrm{m})$} & {$\left[\mathrm{D}_{32}\right](\mu \mathrm{m})$} & Span & Stability & Density $\left(\mathrm{g} \mathrm{mL}^{-1}\right)$ & $\mu(\mathrm{Pa} \cdot \mathrm{s})$ \\
\hline $\mathrm{T} 1$ & $35.70 \mathrm{a} \pm 6.03$ & $0.70 \mathrm{~b} \pm 0.08$ & $5.27 \mathrm{~b} \pm 2.96$ & Stable $^{(2)}$ & $1.110 \mathrm{a} \pm 0.023$ & $0.1778 \mathrm{a} \pm 0.0037$ \\
\hline $\mathrm{T} 2$ & $7.61 \mathrm{c} \pm 1.56$ & $0.30 \mathrm{c} \pm 0.01$ & $23.24 \mathrm{a} \pm 3.55$ & Stable $^{(2)}$ & $1.098 \mathrm{a} \pm 0.018$ & $0.0803 \mathrm{c} \pm 0.0005$ \\
\hline $\mathrm{T} 3$ & $5.81 \mathrm{c} \pm 0.36$ & $0.20 \mathrm{~d} \pm 0.01$ & $5.55 \mathrm{~b} \pm 0.27$ & Stable $^{(2)}$ & $1.095 \mathrm{a} \pm 0.007$ & $0.0717 \mathrm{~d} \pm 0.0006$ \\
\hline $\mathrm{T} 4$ & $1.30 \mathrm{~d} \pm 0.01$ & $0.18 \mathrm{~d} \pm 0.01$ & $2.84 \mathrm{c} \pm 0.01$ & Stable $^{(2)}$ & $1.099 \mathrm{a} \pm 0.011$ & $0.0607 \mathrm{e} \pm 0.0011$ \\
\hline $\mathrm{T} 5$ & $19.90 \mathrm{~b} \pm 0.04$ & $17.30 \mathrm{a} \pm 0.01$ & $1.03 \mathrm{~d} \pm 0.02$ & Instability after 16 hours & $1.067 \mathrm{~b} \pm 0.034$ & $0.1253 \mathrm{~b} \pm 0.0019$ \\
\hline
\end{tabular}

${ }^{(1)}$ Means followed by equal lowercase letters, in the columns, do not differ among themselves, by Scott-Knott's test, at $5 \%$ probability. ${ }^{(2)}$ No formation of apparent instability until 24 hours later. T1, gum arabic; T2, gum arabic + cassava maltodextrin 10DE; T3, gum arabic + maize maltodextrin 10DE; T4, gum arabic + maize maltodextrin 20DE; T5, gum arabic + OSA starch. Mean value \pm standard deviation $(\mathrm{n}=3)$. 

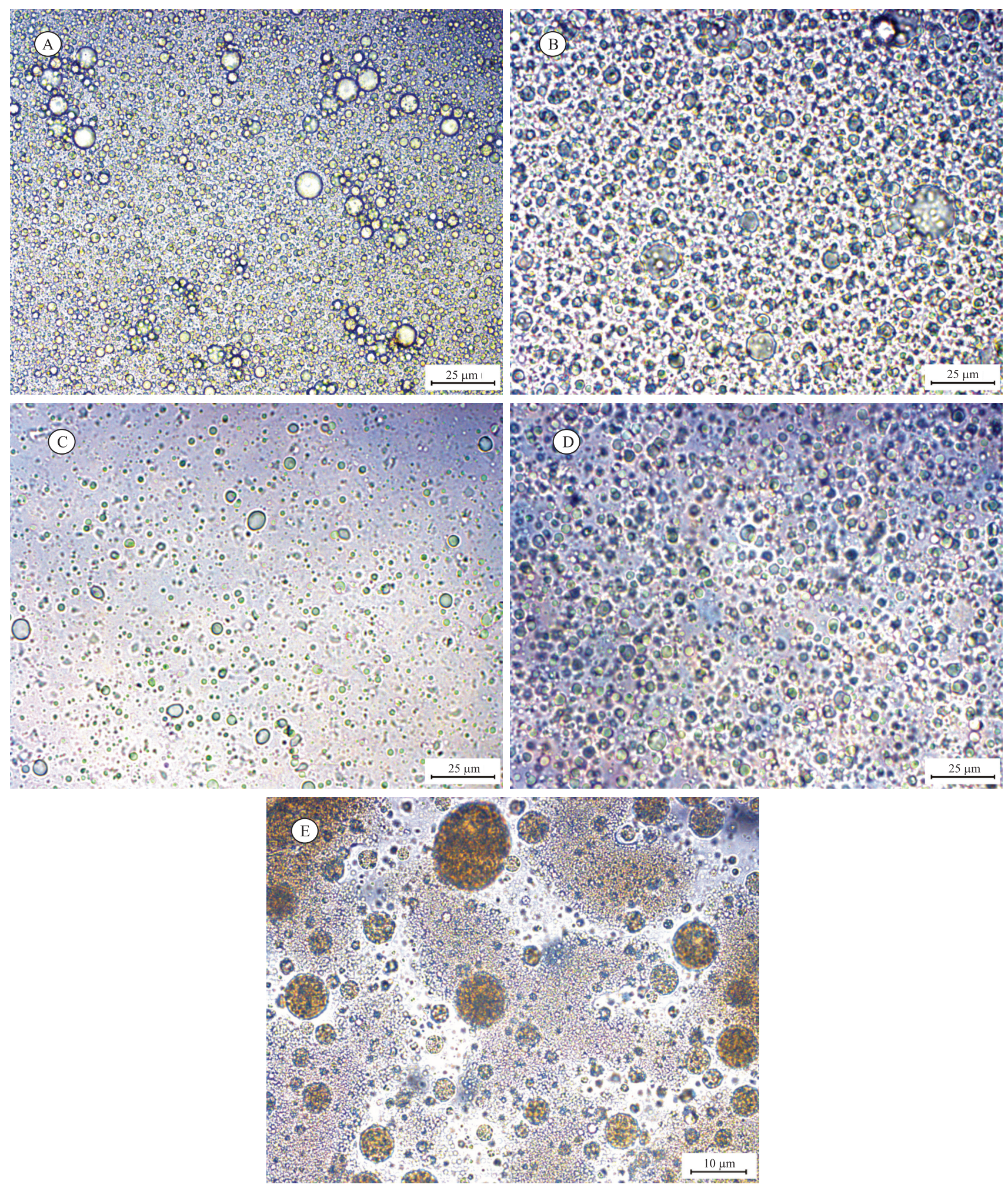

Figure 2. Droplet micrographs of the ultrasound-assisted emulsions with biopolymers for spray drying of lemongrass (Cymbopogon flexuosus) essential oil. A, T1, gum arabic; B, T2, gum arabic + cassava maltodextrin 10DE; C, T3, gum arabic + maize maltodextrin 10DE; D, T4, gum arabic + maize maltodextrin 20DE; E, T5, gum arabic + OSA starch. 
polymers for the preparation and maintenance of the studied emulsion. Nevertheless, the instability process was observed only after 16 hours of its preparation, which ensures the homogeneity long enough to perform the entire drying process.

The pure lemongrass essential oil showed 0.860 g $\mathrm{mL}^{-1}$ density at $25^{\circ} \mathrm{C}$, which corroborates the literature values (Alzawqari et al., 2016). When evaluating the visual characteristics of the emulsions, a greater presence of air bubbles was observed in the micrographs of the treatment with OSA starch (T5). Air bubbles tend to decrease the emulsion density, which negatively affects its stability.

Among the models used to describe the rheological behavior of the treatments, the Newton's law model showed the best adjustments to the experimental data, with high coefficient of determination $(0.9996 \leq$ $\left.\mathrm{R}^{2} \leq 0.9999\right)$ values and low root mean square error $(0.0252 \leq \mathrm{RMSE} \leq 0.2246)$ values. The viscosity data $(\mu)$ determined by the Newton's law model were significant, at 5\% probability, among all tested treatments (Table 2). The Newtonian viscosity values ranged from 0.0607 to $0.1778 \mathrm{~Pa} \cdot \mathrm{s}$. The rheological behavior of emulsions and the effect of partial substitution of gum arabic by modified starches in the different treatments (Figures $3 \mathrm{~A}$ and $3 \mathrm{~B}$ ) showed the relationship between shear stress $(\mathrm{Pa})$ and viscosity $(\mathrm{Pa} \cdot \mathrm{s})$ variations, respectively, as a function of the shear rate $\left(\mathrm{s}^{-1}\right)$. In general, the fluids maintained their Newtonian characteristic, but with inferior viscosities than the carrier material constituted exclusively of gum arabic.

Shear stress as a function of the shear rate showed a linear tendency to Newtonian fluid behavior. (Figure $3 \mathrm{~A}$ ). Such behavior suggests that, for a given temperature, the viscosity will remain constant, regardless of time and shear rate, which was observed in the present study (Figure $3 \mathrm{~B}$ ). The wall material exclusively composed of gum arabic (T1) showed higher Newtonian viscosity value, in the following order of treatments: with OSA starch (T5), cassava maltodextrin-10DE (T2), maize maltodextrin 10DE, and 20DE (T3, T4). This result corroborates the following findings: gum arabic shows good emulsionstabilizing properties and has a branched structure with long chains, which explains its higher viscosity (Mohammadi-Gouraji et al., 2017); OSA starch is an effective emulsifier with lower viscosity than gum arabic because the hydrophobicity of OSA molecules is introduced, which is due to the esterification process, however the hydrophilicity of the starch molecule is maintained (No \& Shin, 2019); and, maltodextrin is a traditional wall material for encapsulating volatile compounds, since it imparts good film forming and low viscosity properties (Campelo et al., 2017).

The high yield of the process is extremely important for the industrial parameters, since the waste of raw
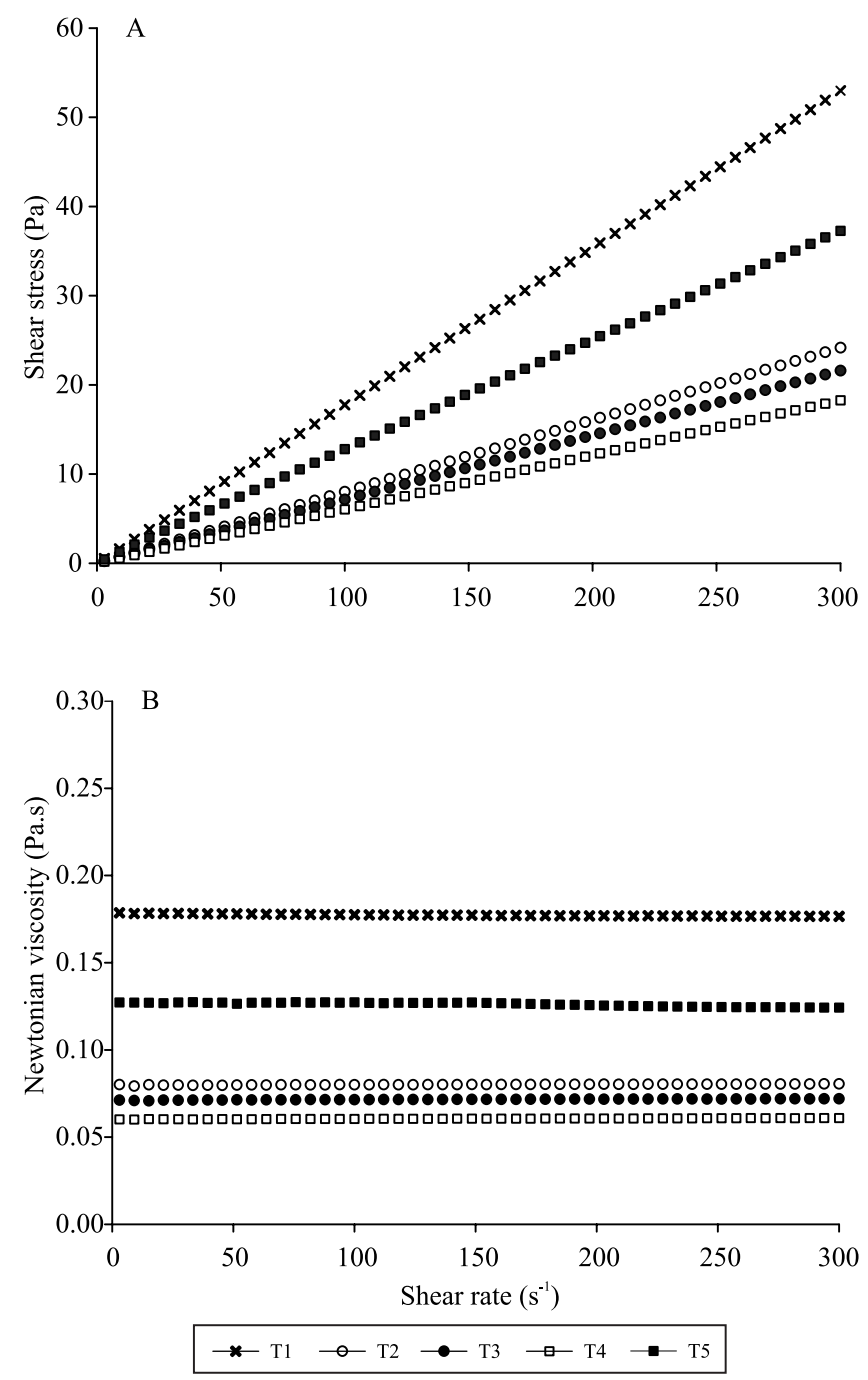

Figure 3. Rheological behavior of the ultrasound-assisted emulsions with biopolymers for spray drying of lemongrass (Cymbopogon flexuosus) essential oil: A, relationship between shear stress and shear rate; and B, relationship between Newtonian viscosity and shear rate. T1, gum arabic; T2, gum arabic + cassava maltodextrin 10DE; T3, gum arabic + maize maltodextrin 10DE; T4, gum arabic + maize maltodextrin 20DE; T5, gum arabic + OSA starch. 
material and energy entails higher costs. The yield was calculated on the amount of collected powder in the collector, by the amount of inlet dry matter (Chandrapala \& Vasiljevic, 2017), on a dry basis. Table 3 presents the values found for the process yield and lemongrass essential oil load.

The process yield was higher when only gum arabic was used as wall material (T1), followed by the treatment with substitution by OSA starch (T5). The substitution by maize maltodextrin (20DE) (T4) showed the lowest yield in the process, averaging $17.2 \%$. The yield of the treatment with maltodextrin 20DE was lower than when the other maltodextrins were applied, which is probably due to the smaller size of its polymer chain (Chaudhary et al., 2017) and its lower glass transition temperature, which consequently gave to the final product a tendency to stick more in the drying chamber of the equipment. Therefore, the substitution of gum arabic caused reduction of the recovery yield of powders; however, this parameter depends on variables related to the equipment construction, such as the shape and size of the drying chamber (Lao \& Giusti, 2017).

The oil load percentage was higher in the treatment with the substitution by OSA starch, and it was lower in the substitution by maize maltodextrin (20DE), with $16.4 \%$ and $11.0 \%$, respectively. When heated at high temperatures $\left(120\right.$ to $\left.170^{\circ} \mathrm{C}\right)$, OSA starch is transformed into dextrin, exhibiting higher water solubility and lower viscosity; however, it maintains its emulsifying capacity (Wang et al., 2011), which allows its use at a high content of solids in comparison to gum arabic, as an encapsulating agent, since it has a great ability to protect substances during spray

Table 3. Spray-drying process yield of the ultrasoundassisted emulsions with biopolymers and lemongrass essential (Cymbopogon flexuosus) oil load ${ }^{(1)}$.

\begin{tabular}{lcc}
\hline Treatment & Process yield (\%) & Oil load (\%) \\
\hline T1 & $52.9 \pm 1.8 \mathrm{a}$ & $13.8 \pm 0.4 \mathrm{~b}$ \\
T2 & $38.5 \pm 1.3 \mathrm{c}$ & $13.5 \pm 0.2 \mathrm{~b}$ \\
T3 & $40.1 \pm 0.9 \mathrm{c}$ & $13.0 \pm 0.2 \mathrm{~b}$ \\
T4 & $17.2 \pm 0.7 \mathrm{~d}$ & $11.0 \pm 0.1 \mathrm{c}$ \\
T5 & $45.3 \pm 0.3 \mathrm{~b}$ & $16.4 \pm 0.5 \mathrm{a}$ \\
\hline
\end{tabular}

(1) Means followed by equal lowercase letters, in the columns, do not differ among themselves, by Scott-Knott's test, at 5\% probability. T1, gum arabic; T2, gum arabic + cassava maltodextrin 10DE; T3, gum arabic + maize maltodextrin 10DE; T4, gum arabic + maize maltodextrin 20DE; $\mathrm{T} 5$, gum arabic + OSA starch. Mean value \pm standard deviation $(\mathrm{n}=3)$. drying. Therefore, despite the occurrence of emulsion coalescence instability with the use of OSA starch, it was not sufficient to influence negatively the encapsulated oil content.

There were no significant differences between T1 (gum arabic), T2 (cassava maltodextrin 10DE), and T3 (maize maltodextrin 10DE) for oil load. Maltodextrins have been studied as possible substitutes for gum arabic in sprayed emulsions, due to their low viscosity at high concentrations, low cost, and their ability to form a film that protects the encapsulated material (Botrel et al., 2017). The results indicate that differences were obtained for the oil content carried by the microparticles, which is due to the material type, but also to the emulsion characteristics. The effect of oil droplet size on the emulsions and the viscosity effect on the oil content are therefore verified.

Despite the incompatibility between OSA starch and gum arabic in the emulsion, observed after 16 hours, the time between the emulsion production and its spray drying is short; therefore, the emulsions in these cases have not suffered the effects of this destabilization. Thus, the joint action of these wall materials on lemongrass essential oil encapsulation was positive, ensuring a higher oil content in the microparticles than in the other treatments. However, the presence of maltodextrin with lower polymer chain had an inverse effect and promoted a reduction in the content of carrier oil.

\section{Conclusions}

1. Modified starch with octenyl succinic anhydride (OSA starch), in partial replacement for gum arabic $(1: 1, \mathrm{w} / \mathrm{w})$, provides greater retention of lemongrass (Cymbopogon flexuosus) essential oil, after spray drying.

2. Maltodextrin dextrose equivalent 10 (10DE) shows a statistically similar oil load to the treatment with gum arabic, while the presence of maize maltodextrin DE20 reduces the content of encapsulated oil and the efficiency of the drying process due to the adherence of particles to the chamber.

3. The partial substitution of gum arabic, mainly by OSA starch, is shown as an alternative in the formation of emulsions for the spray-drying microencapsulation of lemongrass essential oil. 


\section{Acknowledgments}

To Conselho Nacional de Desenvolvimento Científico e Tecnológico (CNPq) and to Fundação de Amparo à Pesquisa do Estado de Minas Gerais (Fapemig), for financial support; and to Coordenação de Aperfeiçoamento de Pessoal de Nível Superior (Capes), for financing, in part, this study (Finance Code 001).

\section{References}

ALZAWQARI, M.H.; AL-BADDANY, A.A.; AL-BAADANI, H.H.; ALHIDARY, I.A.; KHAN, R.U.; AQIL, G.M.; ABDURAB, A. Effect of feeding dried sweet orange (Citrus sinensis) peel and lemon grass (Cymbopogon citratus) leaves on growth performance, carcass traits, serum metabolites and antioxidant status in broiler during the finisher phase. Environmental Science and Pollution Research International, v.23, p.17077-17082, 2016. DOI: https://doi.org/10.1007/s11356-016-6879-7.

BINSI, P.K.; NAYAK, N.; SARKAR, P.C.; JEYAKUMARI, A.; MUHAMED ASHRAF, P.; NINAN, G.; RAVISHANKAR, C.N. Structural and oxidative stabilization of spray dried fish oil microencapsulates with gum arabic and sage polyphenols: characterization and release kinetics. Food Chemistry, v.219, p.158168, 2017. DOI: https://doi.org/10.1016/j.foodchem.2016.09.126.

BOTREL, D.A.; BORGES, S.V.; FERNANDES, R.V. de B.; ANTONIASSI, R.; FARIA-MACHADO, A.F. de; FEITOSA, J.P. de A.; PAULA, R.C.M. de. Application of cashew tree gum on the production and stability of spray- dried fish oil. Food Chemistry, v.221, p.1522-1529, 2017. DOI: https://doi.org/10.1016/j. foodchem.2016.10.141

CAMPELO, P.H.; CARMO, E.L. do; ZACARIAS, R.D.; YOSHIDA, M.I.; FERRAZ, V.P.; FERNANDES, R.V. de B.; BOTREL, D.A.; BORGES, S.V. Effect of dextrose equivalent on physical and chemical properties of lime essential oil microparticles. Industrial Crops and Products, v.102, p.105-114, 2017. DOI: https://doi.org/10.1016/j.indcrop.2017.03.021.

CARNEIRO, H.C.F.; TONON, R.V.; GROSSO, C.R.F.; HUBINGER, M.D. Encapsulation efficiency and oxidative stability of flaxseed oil microencapsulated by spray drying using different combinations of wall materials. Journal of Food Engineering, v.115, p.443-451, 2013. DOI: https://doi.org/10.1016/j.jfoodeng.2012.03.033.

CHANDRAPALA, J.; VASILJEVIC, T. Properties of spray dried lactose powders influenced by presence of lactic acid and calcium. Journal of Food Engineering, v.198, p.63-71, 2017. DOI: https://doi.org/10.1016/j.jfoodeng.2016.11.017.

CHAUDHARY, V.; PANYOYAI, N.; SMALL, D.M.; SHANKS, R.A.; KASAPIS, S. Effect of the glass transition temperature on alpha-amylase activity in a starch matrix. Carbohydrate Polymers, v.157, p.1531-1537, 2017. DOI: https://doi.org/10.1016/j. carbpol.2016.11.028.

DEHSHIBI, R.R.; MOHEBBI, A.; RIAZI, M.; NIAKOUSARI, $M$. Experimental investigation on the effect of ultrasonic waves on reducing asphaltene deposition and improving oil recovery under temperature control. Ultrasonics Sonochemistry, v.45, p.204212, 2018. DOI: https://doi.org/10.1016/j.ultsonch.2018.03.023.

ERDMANN, M.E.; LAUTENSCHLAEGER, R.; ZEEB, B.; GIBIS, M.; WEISS, J. Effect of differently sized $\mathrm{O} / \mathrm{W}$ emulsions loaded with rosemary extract on lipid oxidation in cooked emulsion-type sausages rich in n-3 fatty acids. LWT - Food Science and Technology, v.79, p.496-502, 2017. DOI: https://doi.org/10.1016/j.lwt.2016.03.022.

FERNANDES, R.V. de B.; BORGES, S.V.; BOTREL, D.A. Gum arabic/starch/maltodextrin/inulin as wall materials on the microencapsulation of rosemary essential oil. Carbohydrate Polymers, v.101, p.524-532, 2014. DOI: https://doi.org/10.1016/j. carbpol.2013.09.083.

GAONKAR, R.; YALLAPPA, S.; DHANANJAYA, B.L.; HEGDE, G. Development and validation of reverse phase high performance liquid chromatography for citral analysis from essential oils. Journal of Chromatography B, v.1036-1037, p.5056, 2016. DOI: https://doi.org/10.1016/j.jchromb.2016.10.001.

GOIBIER, L.; LECOMTE, S.; LEAL-CALDERON, F.; FAURE, C. The effect of surfactant crystallization on partial coalescence in $\mathrm{O} / \mathrm{W}$ emulsions. Journal of Colloid and Interface Science, v.500, p.304-314, 2017. DOI: https://doi.org/10.1016/j.jcis.2017.04.021.

HADJILOUKA, A.; MAVROGIANNIS, G.; MALLOUCHOS, A.; PARAMITHIOTIS, S.; MATARAGAS, M.; DROSINOS, E.H. Effect of lemongrass essential oil on Listeria monocytogenes gene expression. LWT - Food Science and Technology, v.77, p.510-516, 2017. DOI: https://doi.org/10.1016/j.lwt.2016.11.080.

KOKKALA， J.; SÄRKKÄ, S. On the (non-)convergence of particle filters with Gaussian importance distributions. IFAC-PapersOnLine, v.48, p.793-798, 2015. DOI: https://doi.org/10.1016/j.ifacol.2015.12.226.

LAO, F.; GIUSTI, M.M. The effect of pigment matrix, temperature and amount of carrier on the yield and final color properties of spray dried purple corn (Zea mays L.) cob anthocyanin powders. Food Chemistry, v.227, p.376-382, 2017. DOI: https://doi.org/10.1016/j.foodchem.2017.01.091.

LI, R.; ROOS, Y.H.; MIAO, S. Characterization of mechanical and encapsulation properties of lactose/maltodextrin/WPI matrix. Food Hydrocolloids, v.63, p.149-159, 2017. DOI: https://doi.org/10.1016/j.foodhyd.2016.08.033.

MOHAMMADI-GOURAJI, E.; SHEIKH-ZEINODDIN, M.; SOLEIMANIAN-ZAD, S. Effects of Persian gum and gum Arabic on the survival of Lactobacillus plantarum PTCC 1896, Escherichia coli, Xanthomonas axonopodis, and Saccharomyces cerevisiae during freeze drying. British Food Journal, v.119, p.331-341, 2017. DOI: https://doi.org/10.1108/BFJ-09-2016-0442.

NADERI, B.; KERAMAT, J.; NASIRPOUR, A.; AMINIFAR, M. Complex coacervation between oak protein isolate and gum Arabic: optimization \& functional characterization. International Journal of Food Properties, v.23, p.1854-1873, 2020. DOI: https://doi.org/10.1080/10942912.2020.1825484.

NIU, F.; NIU, D.; ZHANG, H.; CHANG, C.; GU, L.; SU, Y.; YANG, Y. Ovalbumin/gum arabic-stabilized emulsion: rheology, emulsion characteristics, and Raman spectroscopic 
study. Food Hydrocolloids, v.52, p.607-614, 2016. DOI: https://doi.org/10.1016/j.foodhyd.2015.08.010.

NO, J.; SHIN, M. Preparation and characteristics of octenyl succinic anhydride-modified partial waxy rice starches and encapsulated paprika pigment powder. Food Chemistry, v.295, p.466-474, 2019. DOI: https://doi.org/10.1016/j.foodchem.2019.05.064.

OKOH, S.O.; IWERIEGBOR, B.C.; OKOH, O.O.; NWODO, U.U.; OKOH, A.I. Bactericidal and antioxidant properties of essential oils from the fruits Dennettia tripetala G. Baker. BMC Complementary and Alternative Medicine, v.16, art.486, 2016. DOI: https://doi.org/10.1186/s12906-016-1459-4.

OLIVEIRA, É.R.; FERNANDES, R.V.B.; BOTREL, D.A.; CARMO, E.L.; BORGES, S.V; QUEIROZ, F. Study of different wall matrix biopolymers on the properties of spray-dried pequi oil and on the stability of bioactive compounds. Food and Bioprocess Technology, v.11, p.660-679, 2018. DOI: https://doi.org/10.1007/ s11947-017-2027-8.

OTÁLORA, M.C.; CARRIAZO, J.G.; ITURRIAGA, L.; NAZARENO, M.A.; OSORIO, C. Microencapsulation of betalains obtained from cactus fruit (Opuntia ficus-indica) by spray drying using cactus cladode mucilage and maltodextrin as encapsulating agents. Food Chemistry, v.187, p.174-181, 2015. DOI: https://doi.org/10.1016/j.foodchem.2015.04.090.

SCHMITZ-SCHUG, I.; KULOZIK, U.; FOERST, P. Modeling spray drying of dairy products: impact of drying kinetics, reaction kinetics and spray drying conditions on lysine loss. Chemical Engineering Science, v.141, p.315-329, 2016. DOI: https://doi.org/10.1016/j.ces.2015.11.008.
SILVA, E.K.; MEIRELES, M.A.A. Influence of the degree of inulin polymerization on the ultrasound-assisted encapsulation of annatto seed oil. Carbohydrate Polymers, v.133, p.578-586, 2015. DOI: https://doi.org10.1016/j.carbpol.2015.07.025.

SUI, X.; BI, S.; QI, B.; WANG, Z.; ZHANG, M.; LI, Y.; JIANG, L. Impact of ultrasonic treatment on an emulsion system stabilized with soybean protein isolate and lecithin: its emulsifying property and emulsion stability. Food Hydrocolloids, v.63, p.727-734, 2017. DOI: https://doi.org/10.1016/j.foodhyd.2016.10.024.

SWEEDMAN, M.C.; HASJIM, J.; TIZZOTTI, M.J.; SCHÄFER, C.; GILBERT, R.G. Effect of octenylsuccinic anhydride modification on $\beta$-amylolysis of starch. Carbohydrate Polymers, v.97, p.9-17, 2013. DOI: https://doi.org/10.1016/j. carbpol.2013.04.041.

WANG, B.; WANG, L.-J.; LI, D.; ADHIKARI, B.; SHI, J. Effect of gum Arabic on stability of oil-in-water emulsion stabilized by flaxseed and soybean protein. Carbohydrate Polymers, v.86, p.343-351, 2011. DOI: https://doi.org/10.1016/j. carbpol.2011.04.059.

ZHANG, M.; WANG, A.-J.; LI, J.-M.; SONG, N.; SONG, Y.; HE, R. Factors influencing the stability and type of hydroxyapatite stabilized pickering emulsion. Materials Science and Engineering: C, v.70, p.396-404, 2017. DOI: https://doi.org/10.1016/j.msec.2016.09.007.

ZHENG, S.; JING, G.; WANG, X.; OUYANG, Q.; JIA, L.; TAO, N. Citral exerts its antifungal activity against Penicillium digitatum by affecting the mitochondrial morphology and function. Food Chemistry, v.178, p.76-81, 2015. DOI: https://doi.org/10.1016/j. foodchem.2015.01.077. 